\title{
Decarboxylase activity test of the genus Enterococcus isolated from goat milk and cheese
}

\author{
Libor Kalhotka ${ }^{1}$, Ivan Manga², Jitka Přichystalová1, Michaela Hůlová1, \\ Marcela Vyletělová2, Květoslava Šustováa \\ ${ }^{1}$ Department of Agrochemistry, Soil Science, Microbiology and Plant Nutrition, \\ Faculty of Agriculture, Mendel University in Brno, Czech Republic \\ ${ }^{2}$ Agriresearch Rapotín - Ltd., Vikýřovice, Czech Republic \\ ${ }^{3}$ Department of Food Technology, Faculty of Agriculture, Mendel University in Brno, Czech Republic
}

Received November 16, 2011

Accepted March 7, 2012

\begin{abstract}
Biogenic amines are aliphatic, aromatic or heterocyclic alkalic substances with a biological impact on live organisms. They may cause serious problems to sensitive persons in combination with some medicaments or in case of higher intake. They are present in non-fermented food, usually coming from contaminating microflora, and especially in fermented food where biogenic amines might be produced by microbiota used for procedure. The genus Enterococcus spp. can occur in cheese because their resistance to pasteurizing temperatures is much higher compared to other mesophilic microorganisms. Previous studies have targeted the occurrence and problems of enterococci isolated from cow and sheep milk. The aim of this study was to detect decarboxylase activity of enterococci isolated from goat milk and cheese and to see how the particular temperatures involve decarboxylase activity using a rapid and inexpensive screening method. In this study, bacteria Enterococcus faecium, E. mundtii, E. durans were isolated from 9 samples of goat milk and cheeses. Colonies of bacteria were inoculated on diagnostic medium fortified with amino acids (lysine, arginine, phenylalanine, histidine, tyrosine and tryptophan) and acidity indicator. Changes in colour detected decarboxylase activity of enterococci. The only positive reactions were determined in samples containing arginine and tyrosine. Cultivation of bacteria was confirmed by PCR. All of the tested microorganisms showed significant activity of tyrosindecarboxylase and arginindecarboxylase which was regulated by temperature and influenced by duration of cultivation. The test of decarboxylase activity using colour changes is suitable for a relatively rapid and inexpensive detection of microorganisms that are able to produce biogenic amines.
\end{abstract}

Biogenic amines, microorganisms, amino acid

The ability to decarboxylate amino acids is characteristic for many microorganisms, especially for genera of lactic acid bacteria (Maijala et al. 1993; De Llano et al. 1998; Bover-Cid and Holzapfel 1999; Lonvaud-Funel 2001). Specific enzymes called decarboxylase are produced by microorganisms thus biogenic amines ensue. They are low molecular alkalic substances which have biological consequences. Biogenic amines are naturally present in all living organisms as a necessary source of nitrogen, hormone precursors, protoalkaloids and fytohormones. At high concentrations they can have a toxic effect. Symptoms indicating excessive intake of biogenic amines are vomitus, respiratory problems, sweating, palpitation and hypotension caused by histamine, or hypertension caused by tyramine and fenylethylamine (Velíšek 1999). Amine formation by bacteria is affected by temperature (Halász et al. 1994). The importance of optimal temperature for decarboxylase acidity and formation of biogenic amines is mentioned in studies of Silla Santos (1998), Bover-Cid and Holzapfel (1999) and Greifová et al. (2003).

In fresh milk, non-fermented milk drinks and dairy products, the concentration of biogenic amines is very low because the presence of amines (propylamine, hexylamine, aliphatic 
di- and polyamines, histamine and tyramine) is less than $1 \mathrm{mg} / \mathrm{kg}$. Besides, putrescine, cadaverine, spermin and spermidine may occur there as well (Greifová et al. 2003). The presence of polyamines in cheeses has the most likely origin in milk (Silla Santos 1996). The most important fermented dairy products in terms of the biogenic amines content are cheeses. In cheese, concentrations of protein and free amino acids and present microflora are important for creating relatively high levels of biogenic amines. Besides, the long period of cheese ripening plays an indispensable role. In cheese, the most important biogenic amines are tyramine, histamine, putrescine, cadaverine and phenylethylamine (Kalač and Glória 2009). Cheeses are the second most common causative agent of histamine poisoning (after fish).

A series of procedures and media were created for the determination of decarboxylase activity of microorganisms. They are relatively simple methods using a medium containing a $\mathrm{pH}$ indicator such as Bromcresol Purple to determine formation of biogenic amines (Moeller 1954; Maijala 1993; Bover-Cid and Holzapfel 1999). Within decarboxylation of amino acids, the relevant decarboxylase splits off carboxyl groups $\left(\mathrm{CO}_{2}\right)$ from amino acids and produced alkaline amine gives positive result by discolouration of the indicator due to changes in $\mathrm{pH}$ (Brooks and Sodeman 1974).

Previous studies have targeted the occurrence and problems of enterococci isolated from cow and sheep milk. The aim of this study was to detect decarboxylase activity of enterococci isolated from goat milk and cheese and to see how particular temperatures affect the decarboxylase activity, using a rapid and inexpensive screening method. This study points out potential risks of farm processing of goat milk and cheeses, with regard to the production of ripened cheese associated with the risk of occurrence of enterococci in milk, especially if raw or secondary contaminated milk was processed. While processing, hygiene compliance at a farm is often problematic in comparison to established dairy factories.

\section{Materials and Methods}

Nine isolates of the genus Enterococcus from goat milk and cheese were used for decarboxylase activity test. Isolates originated from these samples: raw goat milk from conventional farming (No. 1, 2, 5, 6 and 7), goat cheese from organic farming (No. 3, 8 and 9), and goat cheese from conventional farming (No. 4).

Samples cultivated on COMPASS Enterococcus Agar (Biokar Diagnostic, France) were isolated for $24 \mathrm{~h}$ at $44{ }^{\circ} \mathrm{C}$. Then multiplication was done on Plate Count Agar with skimmed milk (Biokar Diagnostic, France) at $37^{\circ} \mathrm{C}$ for $72 \mathrm{~h}$. Suspected colonies were isolated on Biolog BUG Agar (Biolog, Inc., USA) and identified using Biolog GEN III MicroLog1 (Biolog, Inc., USA) and using the ENTEROtest with identification program TNW Pro 7.5 (Erba Lachema s.r.o., Czech Republic).

The test of decarboxylase activity was carried out by cultivation in liquid diagnostic media (Brooks and Sodeman 1974). These amino acids were used for the test: lysine, ornithine, arginine, phenylalanine, histidine and tryptophan. Diagnostic medium $(1 \mathrm{ml})$ with the appropriate amino acid was added to tubes. To ensure anaerobic environment, paraffin oil was dripped over the solution. Into prepared sterile medium, 24-h culture was inoculated. Tubes were incubated in a thermostat at $6,25,30$ and $37^{\circ} \mathrm{C}$ for 10 days. During this time, colour changes were evaluated due to production of alkalic amine. During decarboxylation of amino acid contained in diagnostic medium, relevant decarboxylase cleaved $\mathrm{CO}_{2}$ from amino acid thus alkalic amine ensues. Positive result was proved by discolouring of indicator due to a change of $\mathrm{pH}$. Intensity of colour changes was determined visually (- negative reaction; $<1$ weak reaction; $<2$ mesoscale reaction; $<3$ strong reaction).

The bacterial production of histamine and tyrosine was verified using the PCR. The template DNA was extracted using DNA Tissue kit (Macherey-Nagel, Germany) supplemented with $20 \mathrm{mM}$ Tris/HCl, 2mM EDTA, $1 \%$ Triton X-100 and $0.2 \mathrm{mg} / \mathrm{ml}$ lysostaphin lysis buffer. The DNA quality was checked using the Nanodrop Instrument (Thermo Scientific Inc., USA). The primers and the time and temperature profile for detection of 1100 bp PCR product of the $t d c$ gene was performed according to Coton et al. (2004). The PCR test for detection of $h d c$ gene was done according to Coton and Coton (2005) with the specific amplification of $435 \mathrm{bp}$ PCR product and according to Landete et al. (2005) with the detection of $458 \mathrm{bp} h d c$ gene PCR product. The PCR mixture (in $25 \mu$ l volume) composed of $2 X$ PPP Master Mix with the Taq DNA polymerase (Top-Bio Ltd., Praque, Czech Republic); $0.6 \mu \mathrm{M}$ concentration of individual primer sets and 100-150 ng of template DNA. Acquired PCR products were separated at $90 \mathrm{~V} / 1 \mathrm{~h}$ on $1.5 \%$ agarose gel containing ethidium bromide together with DNA Ladder (GeneRuler ${ }^{\mathrm{TM}} 100$ bp DNA Ladder, Fermentas, GmbH, Germany). A negative control containing no template 
and a positive control represented by an enterococcal isolate (Czech Collection of Microorganisms) carrying the tested $h d c$ or $t d c$ gene was included in every set of PCR.

\section{Results}

During 10 days of cultivation at temperatures $6,25,30$ and $37{ }^{\circ} \mathrm{C}, 9$ isolates of enterococci derived from milk a cheese were tested (see Table 1). Isolated bacterial strains were identified as follows: Enterococcus faecium $(\mathrm{n}=5)$, E. durans $(\mathrm{n}=2)$, E. mundtii $(\mathrm{n}=1)$ and one strain was identified only as the genus Enterococcus spp. Under certain conditions all isolates of enterococci were able to decarboxylate amino acids arginine and tyrosine. Amino acids lysine, ornithine, phenylalanine, histamine and tryptophan were not decarboxyled by isolated enterococci at all. Decarboxylation was significantly affected by temperature (Fig. 1). Within cultivation at $6{ }^{\circ} \mathrm{C}$, none of the tested isolates were detected with positive decarboxylase activity. In contrast, at 30 and $37{ }^{\circ} \mathrm{C}$ positive reactions were noted for all samples. Figs 1 and 2 show how temperature affects the intensity of colour reactions during cultivation at $37{ }^{\circ} \mathrm{C}$ for agmatine and at $30{ }^{\circ} \mathrm{C}$ for tyramine. How temperature affects the decarboxylase activity can be seen from figures. Whereas at $30^{\circ} \mathrm{C}$ for tyramine, the reaction of each positive sample was very gentle, reaction at $37^{\circ} \mathrm{C}$ for agmatine was very extensive from the beginning of cultivation (especially in samples 3 and 4). Intensity of colour reactions was also influenced by duration of cultivation. After 10 days of cultivation at $25^{\circ} \mathrm{C}$, tyramine positive reactions were observed in isolates No. 1,3 , 4, 7 and agmatine positive reaction was observed in isolates No. 2, 3, 4, 5 and 7. Although this result means $50 \%$ positive samples for both amino acids, only isolates No. 3, 4, 5 and No. 3, 4 showed a strong positive reaction for arginine and tyrosine, respectively. After 10 days of cultivation at $30{ }^{\circ} \mathrm{C}$, tyramine positive reaction was observed in isolates No. $3,4,6,7$; agmatine positive reaction was observed in isolates No. 1-8. At temperature of $30{ }^{\circ} \mathrm{C}$, percentage of positive samples increased to $66 \%$ but strong positive reactions were observed in isolates No. 3, 4, 5, 6 and No. 3, 4 for arginine and tyrosine, respectively. After 10 days of cultivation at $37^{\circ} \mathrm{C}$, tyramine positive reactions were detected in isolates No. 1 , $3,4,5,8,9$ and agmatine positive reaction was detected in isolates No. 2-9. This means $83 \%$ positive samples, with a strong positive reaction for arginine and tyrosine in isolates No. 2, 3, 4, 5, 7, 8 and for No. 3, 4, respectively.

In our study, we used PCR to evaluate the potential for production of histamine and tyramine in the enterococcal isolates. The PCR confirmed the results of the selective

Table 1 . Intensity of colour changes at $6,25,30$ and $37^{\circ} \mathrm{C}$ after 10 days of cultivation of enterococci for arginine (agmatine) and tyrosine (tyramine)

\begin{tabular}{clllllllcc}
\hline & & \multicolumn{4}{c}{ Agmatine } & \multicolumn{3}{c}{ Tyramine } \\
\cline { 3 - 9 } $\begin{array}{c}\text { No. of } \\
\text { sample }\end{array}$ & $\begin{array}{c}\text { Identified bacterial } \\
\text { species }\end{array}$ & $6^{\circ} \mathrm{C}$ & $25^{\circ} \mathrm{C}$ & $30{ }^{\circ} \mathrm{C}$ & $37{ }^{\circ} \mathrm{C}$ & $6{ }^{\circ} \mathrm{C}$ & $25^{\circ} \mathrm{C}$ & $30^{\circ} \mathrm{C}$ & $37^{\circ} \mathrm{C}$ \\
\hline 1 & Enterococcus faecium & - & - & 0.6 & - & - & 0.3 & - & 0.5 \\
2 & Enterococcus faecium & - & - & 1 & 1.6 & - & - & - & - \\
3 & Enterococcus spp. & - & - & 3 & 3 & - & 2.5 & 3 & 3 \\
4 & Enterococcus mundtii & - & 2.5 & 3 & 3 & - & 1.5 & 3 & 3 \\
5 & Enterococcus faecium & - & 2 & 3 & 3 & - & - & - & 0.6 \\
6 & Enterococcus faecium & - & 3 & 3 & 1.6 & - & - & 0.16 & - \\
7 & Enterococcus faecium & - & 3 & 0.6 & 2 & - & 0.6 & 0.16 & - \\
8 & Enterococcus durans & - & - & 1.5 & 2 & - & - & - & 1 \\
9 & Enterococcus durans & - & 1 & & 1.6 & - & - & - & 2.3 \\
\hline
\end{tabular}

- negative reaction $<1$ weak reaction $<2$ mesoscale reaction $<3$ strong reaction 


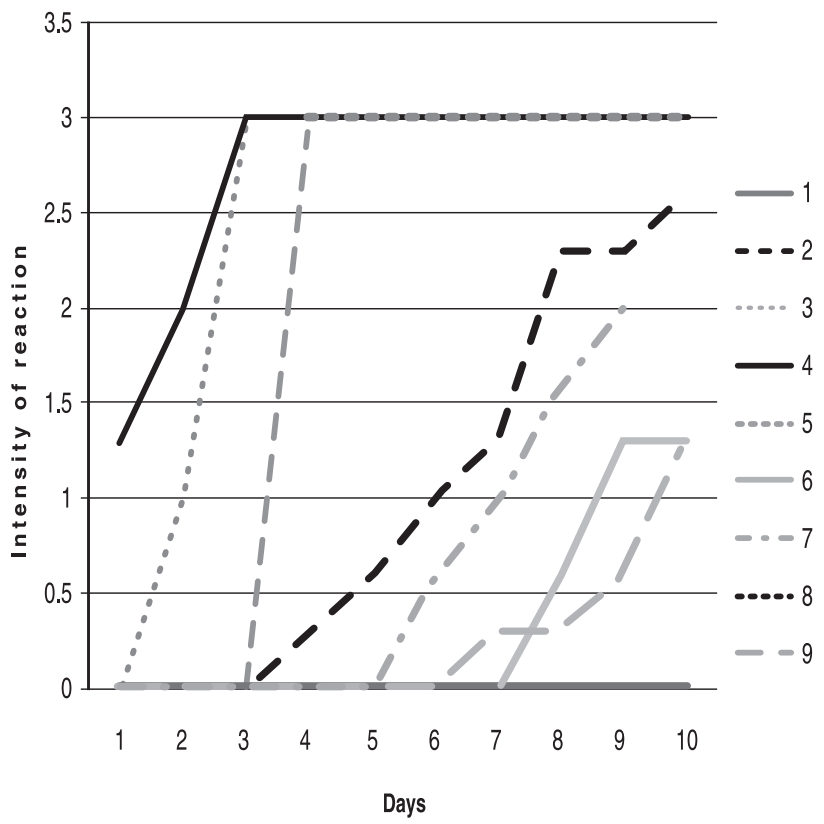

Fig. 1. Decarboxylation of arginine during 10 days at $37^{\circ} \mathrm{C}$

No. 1-9 isolates of enterococci

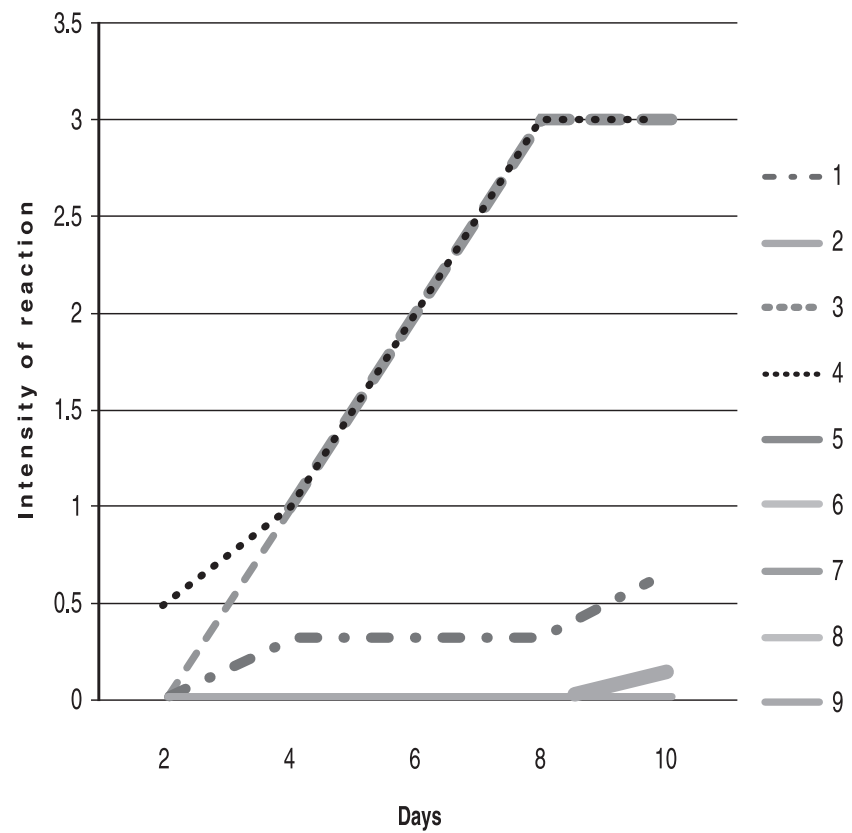

Fig. 2. Decarboxylation of tyrosine during 10 days at $30^{\circ} \mathrm{C}$ 
cultivation methods. None of the tested enterococcal strains carried the $h d c$ gene. In contrast to this, the $t d c$ PCR test revealed presence of this gene in all tested strains.

\section{Discussion}

The genus Enterococcus is an important group of bacteria specific for biogenic amines production. Kalač and Glória (2009) showed that the genus Enterococcus is considered one of the most controversial lactic acid bacteria. Tham et al. (1990) investigated the histamine producing ability of enterococci isolated from cheeses and found that Enterococcus faecalis did not produce histamine and Enterococcus faecium produced this amine in very small amounts. Probably for this reason histidine was not decarboxylated by any of the isolates at any temperature. The decarboxylation was significantly affected by temperature. Beutling (1996) indicates that temperatures below $10{ }^{\circ} \mathrm{C}$ do not allow formation of tyramine due to the inactivation of the enzyme tyrosin decarboxylase (Greifova et al. 2003 ). With regard to possible production of biogenic amines, the temperature of $6{ }^{\circ} \mathrm{C}$ can be considered suitable for the storage of milk and milk products. Bover-Cid and Holzapfel (1999) confirmed that after 4 days cultivation at $37^{\circ} \mathrm{C}$, production of tyramine was confirmed in all tested strains of Enterococcus durans, E. faecalis and E. faecium. Also Halász et al. (1994) and Greifová et al. (2003) reported significant production of tyramine by E. faecalis. As the optimal temperature zone for the formation of tyramine, the value $\left(17-23{ }^{\circ} \mathrm{C}, 27-30{ }^{\circ} \mathrm{C}\right.$, $37^{\circ} \mathrm{C}, 40{ }^{\circ} \mathrm{C}$ ) is indicated by various authors, but data on the boundary values of temperatures are missing (Greifová et al. 2003). Although Gardini et al. (2000) reported that relevant decarboxylase activity of enterococci isolated from dairy products concerned tyrosine, it was found that enterococci showed higher ability to decarboxylate arginine. Enterococci isolated from cheese (samples No. 3 and 4) showed higher decarboxylative activity for tyrosine compared to other samples. Thus enterococci can significantly participate on tyramine production in cheese. During cultivation at $25^{\circ} \mathrm{C}$, first positive results were noted on the second day for agmatine and on the $4^{\text {th }}$ day for tyramine, at $30{ }^{\circ} \mathrm{C}$ and $37{ }^{\circ} \mathrm{C}$ on the first day for agmatine and on the second day for tyramine.

In some cases, the detection of bacteria producing biogenic amines by conventional culture techniques could exhibit low sensitivity or appearance of false positive/ negative results. In addition, negative or positive responses in the screening media do not necessarily imply a similar behaviour in the food (Bover-Cid and Holzapfel 1999). Therefore, new methods applicable for detection of bacteria producing biogenic amines or direct detection of biogenic amines have been developed. Molecular methods intended for identification of individual bacterial decarboxylase genes allowing bacterial production of biogenic amines have became an alternative to traditional culture methods (Landete et al. 2007). None of the tested enterococcal strains carried the $h d c$ gene. In contrast to this, the $t d c$ PCR test revealed the presence of this gene in all tested strains. This indicated a high possibility for production of tyramine in the tested samples and corresponded with the results of selective cultivation in our study. Similar results were found by Kučerová et al. (2009) who monitored the tyrosine decarboxylase activity and the presence of $t d c$ gene among isolates of enterococci obtained from raw cow milk, fresh cheeses and semi-hard cheeses. In their study, twenty out of thirty-three strains possessed tyrosine decarboxylase activity. In the strains with the strongest decarboxylase activity, the presence of $t d c$ gene was confirmed. In another study (Bhardwaj et al. 2009), the $t d c$ gene was present in twenty from twenty-eight enterococcal strains. Moreover, the authors observed $100 \%$ correlation 
between the results obtained with selective cultivation, $t d c$ targeted PCR and tyramine quantification by high performance liquid chromatography.

The genus Enterococcus can occur in cheese because its resistance to pasteurizing temperatures is much higher compared to other mezophilic microorganisms. Thus enterococci could resist the pasteurization of milk or they might come from secondary contamination during cheese manufacturing. It is important to note that although there were microorganisms with decarboxylative activity in milk, at $6{ }^{\circ} \mathrm{C}$ no sample showed a positive reaction during the whole cultivation. On the condition of observing proper storage temperature of milk and cheese, significant production of biogenic amines will not be reached by present enterococci. Despite obvious disadvantages of the test, the decarboxylase activity method using colour changes is suitable for a relatively rapid and inexpensive detection of microorganisms ability to form biogenic amines.

\section{Acknowledgments}

This study was supported by the MŠMT 2B08069 National Research Program - NRV II- program 2B Research of relationships between the characteristics of contaminant microflora and production of biogenic amines as risk toxicants in system of wholesomeness assessment in cheese on consumer market and the research project MSM 2678846201 Enacting of European model of multifunctional agriculture in LFA regions of Czech Republic.

\section{References}

Bhardwaj A, Gupta H, Iyer R, Kumar N, Malik RK 2009: Tyramine-producing enterococci are equally detected on tyramine production medium, by quantification of tyramine by HPLC, or by $t d c$ gene-targeted PCR. Dairy Sci Technol 89: 601-611

Bover-Cid S, Holzapfel WH 1999: Improved screening procedure for biogenic amine production by lactic acid bacteria. Int J Food Microbiol 53: 33-41

Brooks K, Sodeman T 1974: A rapid method for determining decarboxylase and dihydrolase activity. J Clin Pathol 27: $148-152$

Coton E, Coton M 2005: Multiplex PCR for colony directly detection of Gram-positive histamine- and tyramineproducing bacteria. J Microbiol Meth 63: 296-304

Coton M, Coton E, Lucas P, Lonvaud A 2004: Identification of the gene encoding a putative tyrosine decarboxylase of Carnobacterium divergens 508. Development of molecular tools for the detection of tyramine-producing bacteria. Food Microbiol 21: 125-130

De Llano DG, Cuesta P, Rodriguez A 1998: Biogenic amine production by wild lactococcal and leuconostoc strains. Lett Appl Microbiol 26: 270-274

Gardini F, Martusfelli M, Caruso M, Galgano F, Crudela M, Favati F, Guerzoni E, Suzzi G 2000: Effects of pH, temperature and $\mathrm{NaCl}$ concentration on the growth kinetics, proteolytic activity and biogenic amine production of Enterococcus faecalis. Int J Food Microbiol 64: 105-117

Greifová M, Greif G, Novorol'níková B, Kubová A 2003: Biogenic amines in dairy products and their production of enterococci (in Slovak). Mliekarsvo 4: 31-33

Halász A, Baráth A, Simon-Sakardi L, Holzapfel W 1994: Biogenic amines and their production by microorganisms in food. Trends in Food Sci Technol 5: $42-49$

Kalač P, Glória MBA 2009: Biogenic amines in cheeses, wines, beers and sauerkraut. In: Dandrifosse G (Ed.): Biological aspects of biogenic amines, polyamines and conjugates. Transworld Research Network, Trivandrum, India, pp. 267-309

Kučerová K, Svobodova H, Tůma S, Ondračková I, Plocková M 2009: Production of biogenic amines by enterococci. Czech J Food Sci 27: 52-55

Landete JM, Ferrer S, Pardo I 2005: Which are the lactic acid bacteria responsible for histamine production in wine? J Appl Microbiol 99: 580-586

Landete JM, de Las Rivas B, Marcobal A, Muñoz R 2007: Molecular methods for the detection of biogenic amineproducing bacteria on foods. Int J Food Microbiol 117: 258-269

Lonvaud-Funel A 2001: Biogenic amines in wines: role of lactic acid bacteria. FEMS Microbiol Lett 199: 9-13

Maijala R 1993: Formation of histamine and tyramine by some lactic acid bacteria in MRS-broth and modified decarboxylation agar. Lett Appl Microbiol 17: 40-43

Maijala RL, Eerola SH, Aho MA, Hirn JA 1993: The effect of GDL - induced pH decrease on the formation of biogenic amines in meat. J Food Prot 56: 125-129

Moeller V 1954: Distribution of amino acid decarboxylase in Enterobacteriaceae. Acta Pathol Microbiol Scand 35: 259-277

Silla Santos MH 1996: Biogenic amines: their importance in foods. Instututo de Agroquimica y Technologia de 
Alimentos, Valencia. Int J Food Microbiol 29: 213-231

Silla Santos MH 1998: Amino acid decarboxylase capability of microorganisms isolated in Spanish fermented meat products. Int J Food Microbiol 39: 227-230

Tham M, Karp G, Danielson-Tham ML 1990: Histamine formation by enterococci in goat cheese. Int J Food 11: 225 229

Velíšek J 1999: Chemie potravin 3, OSSIS, Tábor, pp. 123-130 